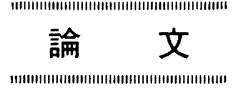

\title{
溶鉄わよび溶鋼の脱窒反応に関する吥究*
}

\author{
成田貴一** . 小山伸二*** . 牧野武久 $* * * \cdot$ 岡村正義 $* * *$
}

\section{A Study on the Nitrogen Desorption Reaction of Liquid Iron and Steel}

\author{
Kiichi Narita, Shinji Koyama, \\ Takehisa MAKino, and Masayoshi OKAMURA
}

\begin{abstract}
Synopsis:
Kinetics of nitrogen desorption reaction of liquid iron and steel has been investigated by means of blowing various gas on the surface of the melt.

The nitrogen desorption reaction of liquid iron is of second order, and the reaction rate is remarkably affected by oxygen content in liquid iron. The rate constant decreases in inverse proportion to the second power of oxygen content above $0.03 \%$, increases gradually below this value of oxygen content and tends to approach a constant value below $0.01 \%$ of oxygen.

From the standpoint of chemisorption of nitrogen atoms on the surface of licuid iron, these results lead to the conclusion that the rate-controlling step is the reaction between these atoms, which is disturbed by adsorbed oxygen atoms.

The activation energy of nitrogen desorption reaction is $39 \mathrm{kcal} / \mathrm{mole}$ in liquid iron containing oxygen less than $0.01 \%$.

When the decarburization and the nitrogen desorption reactions proceed simultaneously by blowing argon and oxygen mixed gas to liquid steel, the latter reaction is deviated from the second order, and its rate becomes considerably slow in comparison with that of liquid iron by blowing only argon. These facts are considered to be caused by the disturbance of the reaction of nitrogen atoms by the oxygen atoms adsorbed on the surface of liquid steel.
\end{abstract}

(Received Feb. 13, 1971)

\section{1. 緒}

\section{言}

窒素が鉄鋼の諸性質に顕著な影響をおよぼすことはよ く知られている・たとえば鋼の高洫強度は窒素により顕 著に改善され，また $\mathrm{Al}$ あるいは $\mathrm{V}$ などにより，鋼の 結晶粒を微細化する場合には適量の空素が必要である.

一方，非時効性の鋼を製造するたわには，鋼中の空素 はできるかぎり低いことが必要になる．したがつて鋼中 の窒素量を調整することは，製鋼過程における重要な課 題のびとつである.

このような意味で, 彷来から溶鉄中における絰素の挙 動，すなわち溶鉄の窒素の溶解度，吸空速度および脱窒 速度などについて多くの研究が抢こなわれている.とく に溶鉄の脱窒反応に関与る研究が最近さかんにおこなわ れている1ー7、。かしはがらその反応機構についてはか ならずしも一致した見解はえられておらず，十分にあき らかにされているとはいいがたい。
一方，LD 転炉製䤱法は他の製鋼法にくらべて，低窒 素鋼を製造するのに最適した片沫であることはよく知 られておら，ての製鋉過程における窒素の挙動に関して も多くの報告があり9２0，現象的にはかなりあきらかに されている，しかしながらLD転炉に打ける粗錦反応そ のものが複雑な現象であることにもより，ての脱窒反応 機楧も十分に解明されているとはいいがたい。

本研究では, 製鋼過程におけら等少の挙動を解明する 上で必要な溶鉄あるい:溶鋼の脱窒反応機楧をあきらか にする目的で $2 ， 3$ の検討をおこなつた。

\section{2. 実 験 方 法}

実験装置は反応炉とガス洗浄装置とからなる. 反応炉

* 昭和45年 4 月本会䋰演大会にて発表 炤和46年 2 月 13 日受付

** (株) 神戸製鋼所中央研究所理博工博

*** (批) 神戸製鋼所中央研究所 
Table 1. Chemical composition of raw material.

\begin{tabular}{c|c|c|c|c|c|c|c}
\hline $\mathrm{C}$ & $\mathrm{Si}$ & $\mathrm{Mn}$ & $\mathrm{P}$ & $\mathrm{S}$ & $\mathrm{Ni}, \mathrm{Cr}, \mathrm{Cu}$ & $\mathrm{O}$ & $\mathrm{N}$ \\
\hline$<0.001$ & 0.008 & 0.01 & 0.002 & 0.007 & $<0.01$ & 0.009 & 0.0022 \\
\hline
\end{tabular}

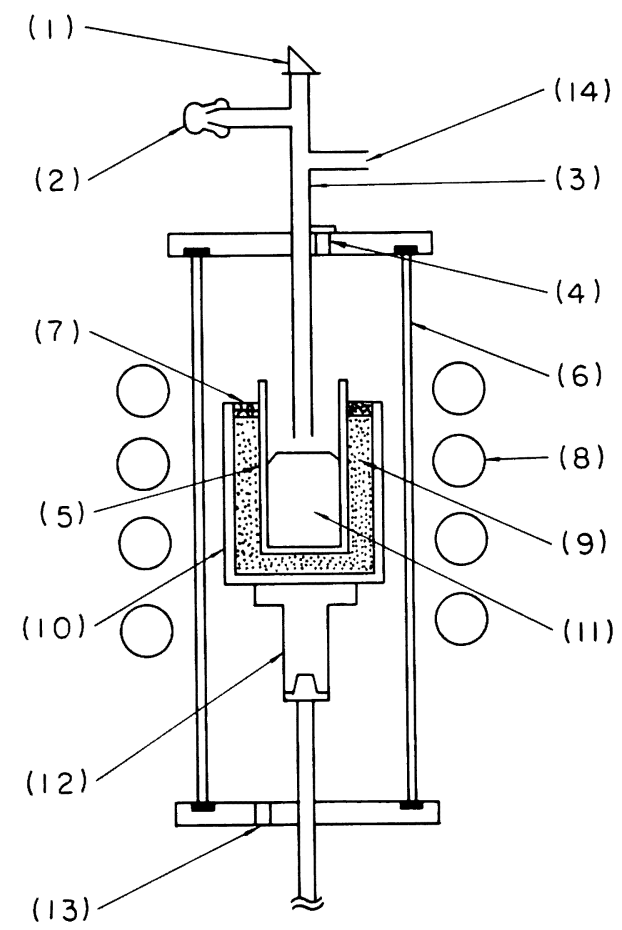

(1) Prism (2) Holder of alloying element added (3) Gas inlet tube (4) Sampling hole (5) Sintered magnesia crucible (6) Quartz tube (7) Magnesia grain (8) Induction heating coil (9) Magnesia powder (10) Alumina crucible (11) Molten iron (12) Alumina supporter (13) Gas outlet (14) Gas inlet

Fig. 1. Experimental apparatus.

の概略を Fig. 1 に示す. ガスの浄化は主として $\mathrm{O}_{2}$ お よび $\mathrm{H}_{2} \mathrm{O}$ の除去を目的とした。

反応管は透明石英管を用い，アルるナるつぼを保護る つぼとし，その中に融解用るつぼとして，内径 $40 \mathrm{~mm}$, 高さ $100 \mathrm{~mm}$ の焼結したマグネシアるつぼを入れ，る つぼ間にマグネシアの細粒を充増した。これらのるつぼ はかる歯車に連結したるつぼ支持台にのせ，上下に自由 に動かすことができる。 さらにAr 導入管としてアルミ ナ管を用い，それがるつぼの中心にくるように設置し た. 実験に使用した $\mathrm{Ar}, \mathrm{N}_{2}, \mathrm{H}_{2}$ は市服のボンベガス であり，それこれ十分に精製後，毛管流量計をへてて反忍 炉に導入した。

溶鉄の脱窒速度を測定する場合には，電解鉄を真空融
解してつくつた Table 1 亿示す成分組成の素材約 500 $\mathrm{g}$ をるつぼに装入し， $25 \mathrm{~kW} ， 400 \mathrm{kC}$ の高周波誘導炉を 用いて $\mathrm{Ar}-\mathrm{H}_{2}$ 父流中で融解する. 溶け落ち後, 溶鉄中 の窒素を $200 \mathrm{ppm}$ 前後にするため, 絰素分圧を調整し た $\mathrm{N}_{2}-\mathrm{Ar}-\mathrm{H}_{2}$ 混合ガスで吸窒をおこなわせ, さらに最 終的に $\mathrm{N}_{2}-\mathrm{Ar}$ 混合ガスで窒素量を所定浱度にする. た酸素漘度を上げる場合には， $\mathrm{Fe}_{2} \mathrm{O}_{3}$ を塊状にしたもの を添加して調節した，溶鉄中の窒素量および酸素量を所 定嶩度に調節したのち，Ar を導入し脱窒反応をおこな わせ，所定時間ごとに内径約 $5 \mathrm{~mm}$ の石英管を用いて約 $8 \mathrm{~g}$ の試料を採取し, 水中に急冷して窒素あるいはその 他の元素の分析に供した. なおガス導入管と溶鉄面の間 隔を一定にするため実験途中で試料採取量に対応してる つぼを適当に上昇させた.

脱窒反心に対する水素の影響を調べる場合には， Ar のかわりに所定量の $\mathrm{H}_{2}$ を混合した $\mathrm{Ar}-\mathrm{H}_{2}$ 混合ガスを 用いて実験をおこなつた。

溶鋼の脱窒反応におよぼす脱炭反応の影響を調べる場 合には，Fe-C 合金を添加して炭素量を約 $1 \%$ に調節し さらに前述と同様にして窒素量を所定濃度にしたのち, $\mathrm{Ar}-\mathrm{O}_{2}$ 混合ガスで脱䇪と同時に脱炭反応をおこなわせ る. 脱炭反応のみをおこなわせた実験もおこなつたが, この場合は窒素の添加をおこなわないだけでほかは同じ である.

窒素は水蒸気蒸留法, 酸素は真空融解法, 炭素は燃焼 法によつて定量した。測温は標準熱電対で補正した光高 温計によりおこなつた、実験温度は一部の実験を除き, いずれも $1600^{\circ} \mathrm{C}$ である。

\section{3. 実 験 結 果}

\section{1 実験条件の検討}

本実験の条件で脱窒反応をおこなわせた場合の脱窒過 程は一応つぎの 5 つ素過程にわけて考えられる.

（1）溶鉄中の窒素原子が高周波の掜拌作用，拡散な どによりガスーメタル界面付近に移動する過程.

（2）ガスーメタル界面付近の溶鉄側境界層における 窒素原子の移動

（3）ガスーメタル界面における窒素分子の生成.

（4）ガスーメタル界面付近のガス側境界層における 窒素分子の移動. 
（5）Ar 気流によつてガス側境界層付近の窒素分子 がもち去られる過程.

これらの 5 つの過程のうちもつともおそい過程が律速段 階になる.（1）の過程は溶鉄が高周波により掜拌される のでバルクは一定濃度と考えられ，律速段階にはなりえ ない，本実験の条件下では (2)および ( 3 )の過程を分離 するような実験をおこなうことはできない（4)および (5)の過程はガスの流量に大きく影響され，ガスの流量 が少ない場合には律速段階になる可能性がある.

そこで本実験では（4)拈よび（5)の過程を無視できる ような条件を決め，（2）抢よび(3)の過程について検討 するために，溶鉄表面への Ar の吹きつけ条件をまず検 討した.

るつぼ中心に設置した内径 $10 \mathrm{~mm}$ のガス導入管より 流量およびガス導入管高さを変化させて Ar を吹きつけ た場合の $[\mathrm{N}]$ の経時変化の一例を Fig. 2 に示す.

従来, 脱侄反応は 2 次反応であるといわれており，そ の速度式は (1) 式で示される.

$$
-d[\% \mathrm{~N}] / d t=(A / V) k[\% \mathrm{~N}]^{2}
$$

これを積分すると(2)式がえられる。

$$
1 /[\% \mathrm{~N}]-1 /[\% \mathrm{~N}]_{0}=(A / V) k t
$$

ただし， $[\% \mathrm{~N}]_{0},[\% \mathrm{~N}]: t=0$ および $t$ における溶鉄中 窒素濃度, $(\%)$

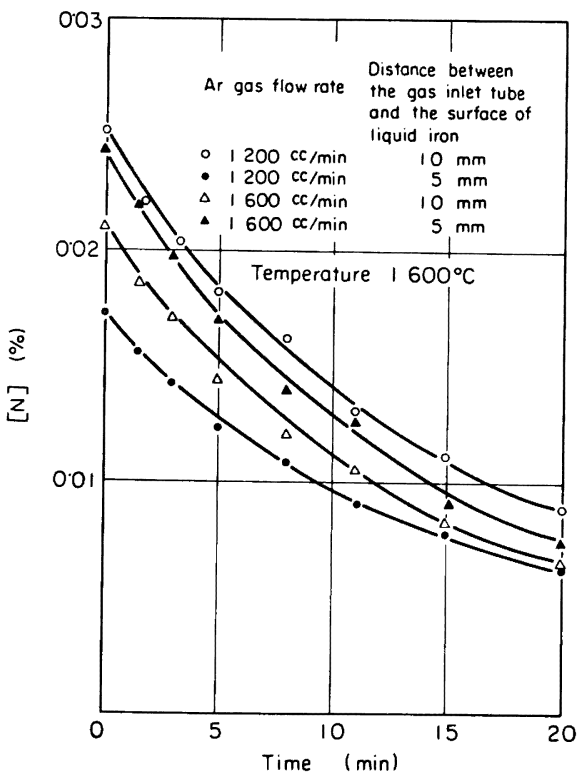

Fig. 2. Change of nitrogen content during the desorption reaction of nitrogen in liquid iron.

$$
\begin{aligned}
& A: \text { ガス-溶鉄界面積, }\left(\mathrm{cm}^{2}\right) \\
& V: \text { 溶鉄の休皘, }\left(\mathrm{cm}^{3}\right) \\
& k: \text { 速度定数, }(\mathrm{cm} / \% \cdot \mathrm{sec}) \\
& t: \text { 時間, }(\mathrm{sec})
\end{aligned}
$$

そこで Fig. 2 の結果に(2)式を適用し，解析した結 果を Fig. 3 に示す.この四からあきらかなように，本 実験においても脱空速度は 2 次式によく一致しているこ とがわかる.したがつて以後の解析は 2 次反応としてと りあつかつた。

脱窒反心に対するガス側の抵抗を舆視できる条件を決 定するために，ガス導入管高さを变化させた場合の速度 定数におよぼす Ar 流量の影響を梌討した結果をFig. 4 に示す.な㧍ここで溶鉄中の酸素量は $0.005 〜 0.009 \%$ に調整した。このようにガス導入管内径および高さにほ ぼ無関倸に， $1000 \mathrm{cc} / \mathrm{min}$ 以上で速度定数は一定とな る.

森ら5゙管径 $10 \mathrm{~mm}$ ，ガス導入管高さ 5 および $10 \mathrm{~mm}$

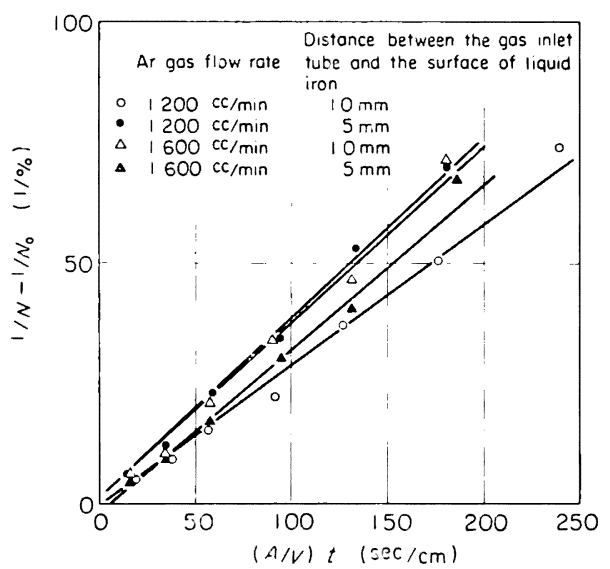

Fig. 3. Relation between $\left(1 / N-1 / N_{0}\right)$ and $(A / V) t$ during the desorption reaction of nitrogen in liquid iron.

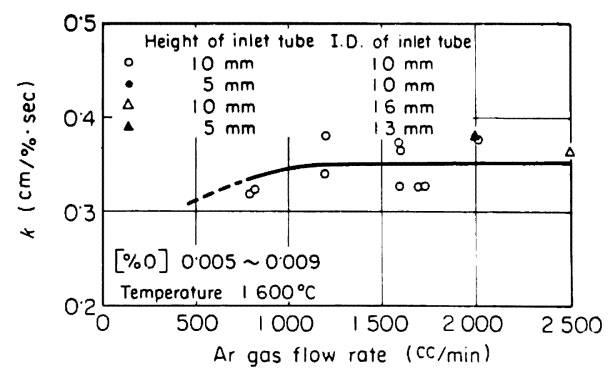

Fig. 4. Effect of Ar gas flow rate on the rate constant of nitrogen desorption in liquid iron. 
で同根の䒠験をおこない，本実験と间掋公結果を得てい る. なた不破ら ${ }^{334)}$ は管径 $20 \mathrm{~mm}$, ガ 只導入管高さ 2 〜 mm で同様の結果艺得ている.

以上のように，各研究者ひ主除条作はガス側の抵抗を 十分に艋視しうる条件であることがわかる。したがつて 本実験では，実験の容易さを考少して，管径 $10 \mathrm{~mm} ，$ カ 又導入管高さを $10 \mathrm{~mm}$ とし, Ar 流量を $1600 \mathrm{cc} / \mathrm{min}$ として以徣ひ过験をおこ斿つた。

脱空反応あるいは脱炭反応と脱窑反応とをあわせてお

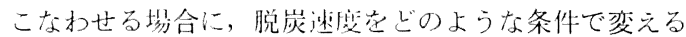

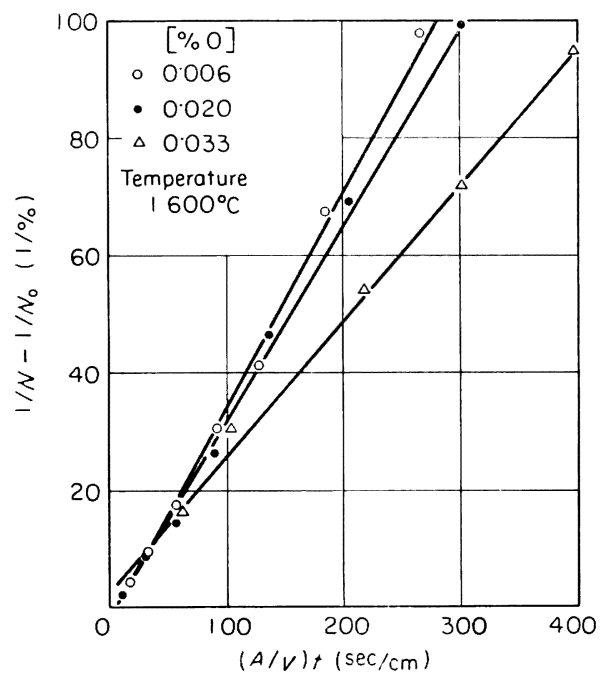

Fig. 5- a . Relation between $\left(1 / N-1 / N_{0}\right)$ and $(A /$ $V) t$ during nitrogen desorption of liquid iron containing various amount of oxygen.

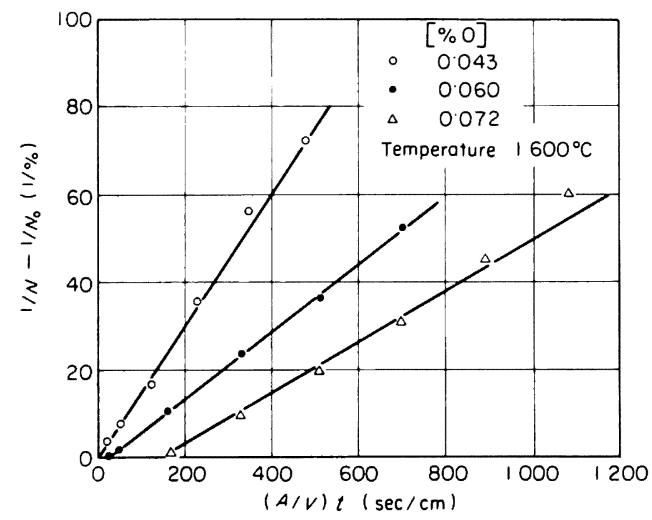

Fig. 5-b. Relation between $\left(1 / N-1 / N_{0}\right)$ and $(A /$ $V) t$ during nitrogen desorption of liquid iron containing various amount of oxygen.
かということが問題であるが，本実験の目的が脱窒反応 の機棈の解明にあるので, 脱窒反応でガス側の抵抗が無 視できる条件,すなわらガス導入管径を $10 \mathrm{~mm}$ にし,ガ 不導入管高さを $10 \mathrm{~mm}$ にして吹きつけガス流量を 1600 $\mathrm{cc} / \mathrm{min}$ にした．脱炭速度は吹きつけガスの $\mathrm{O}_{2}$ 分旺を 変えて調整した。

\section{$3 \cdot 2$ 溶鉄の脱窒反応におよぼす酸素濃度および温度の 影響}

优来，吸空速度あるいは脱空速度に関する研究におい て，溶鉄中の酸素がそれらの速度に著しい影響をおよぼ すことが報告されている，そこで本実験においてもまず その影響について調べた。

Fig. 5-a および 5-b に酸素浱度を変化させた場合の $\left(1 /[\mathrm{N}] 0-1 /[\mathrm{N}]_{0}\right)$ と $(A / V) t$ の関倸を示す. このよ うに酸素浱度に関係なく脱窒反応に対しては，2次反応 の速度式が適用できることがわかる.この結果から求め た速度定数と酸素浱度の関係を Fig. 6 に示す. 0.02 $[0, \mathrm{O}]$ 以上て速度定数は著しく低下するが，0.01 [\% 以下ではその変化は少なく, ほぼ一定値を示す. 図中に 他の研究者らの值を示したが，ほぼ同様の挙動を示し， また速度定数の絶対倠も他の研究者らの值とかなり一致 していることがわかる。

つぎに酸素裖度を0.006〜0.011\%の範囲でほぼ一定に 保つた場合の速度定数におよぼす温度の影響を調べた。 温度を $1560^{\circ} \sim 1700^{\circ} \mathrm{C}$ の範囲で変化させ，(1/[N]$\left.1 /[\mathrm{N}]_{0}\right)$ ¿ $(A / V) t$ の関係を調べた結果を Fig. 7 に 示寸.そしてこの図から得られた速度定数と $1 / T$ との 関係を Fig. 8 に示す. 速度定数と $1 / T$ との間に

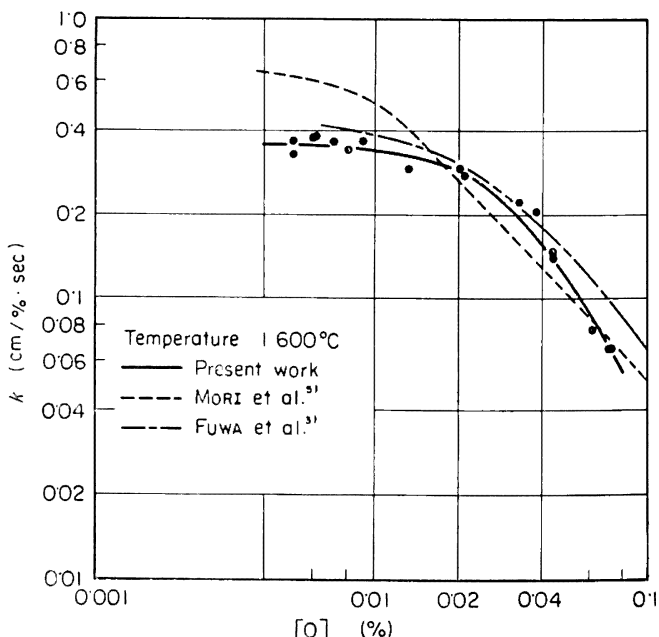

Fig. 6. Dependence of the rate constant of nitrogen desorption on oxygen content in liquid iron. 


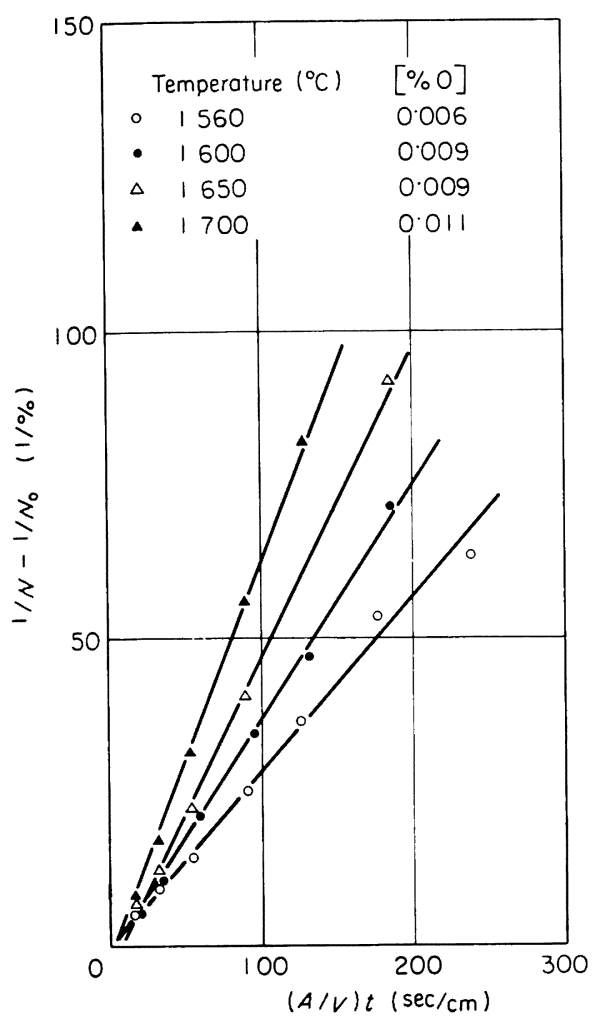

Fig. 7. Effect of temperature on the relation between $\left(1 / N-1 / N_{0}\right)$ and $(A / V) t$.

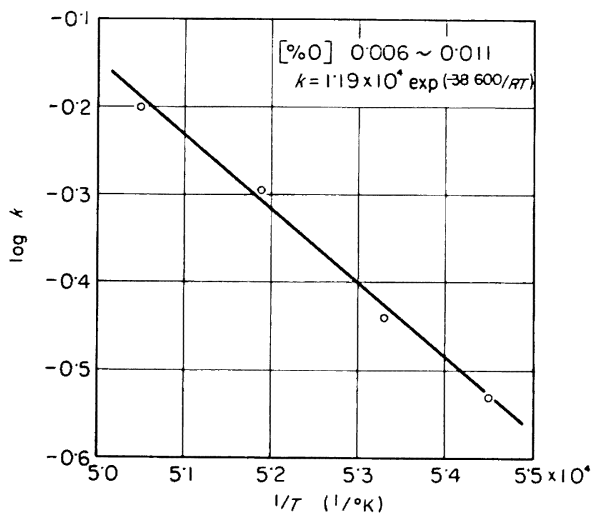

Fig. 8. Effect of temperature on the rate constant of nitrogen desorption.

Arrhenius の関係が成立するとみなすことができ(3)式 の関係が得られる.

$$
\begin{gathered}
k=1 \cdot 19 \times 10^{4} \exp (-38600 / R T) \\
{[\% \mathrm{O}]: 0.006 \sim 0.011}
\end{gathered}
$$

すなわち活性化エネルギーとして約 $39 \mathrm{kcal} / \mathrm{mol}$ が得ら

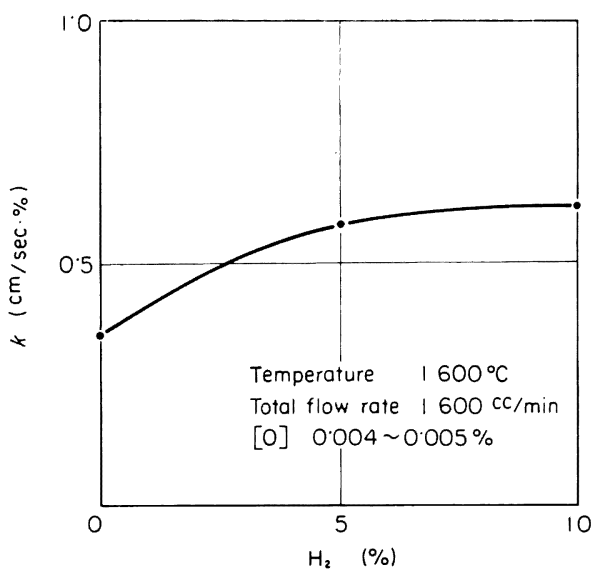

Fig. 9. Effert of hydrogen mixed with argon on the rate constant of nitrogen desorption.

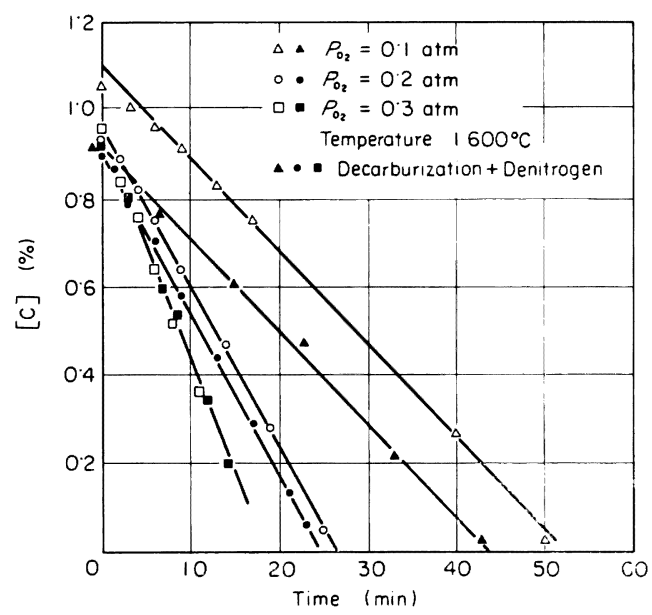

Fig. 10. Change of carbon content during decarburization reaction in liquid steel.

れたこの值は盛らのの $0.005[\% \mathrm{O}]$ における值 $36 \mathrm{kcal} /$ $\mathrm{mol}$, 森ら5) の0.004 0.006[\%O]に活方值 $32 \mathrm{kcal} /$ $\mathrm{mol}$ と比較的によく一致している.

\section{3 溶鉄の脱窒速度におよぼす水素の影響}

$\mathrm{Ar}+\mathrm{H}_{2}$ の総流量を $1600 \mathrm{cc} / \mathrm{min}$ として脱窒反応を

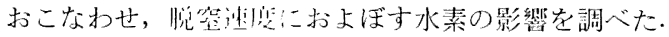
この場合も脱窒反応山2 次反応の速度式で解析できる. 実験前後の溶鉄中の酸素量は $0.0041 \sim 0.0044 \%$ の籁 囲で汪とんど変化していない，速度定数とガス中の $\mathrm{H}_{2}$ 量との関係を Fig. 9 に示す.このようにAr 中に微量 の $\mathrm{H}_{2}$ を混合して脱窒反応をおこなわせるこ脱窒速度が 促進されるが， $\mathrm{H}_{2}$ 省さらに多くしてもとの影樂はほ とんどあらわれなくなることがわかる。 


\section{4 脱炭反応に関する実験結果}

本研究は脱窒反応の機構の解明が目的であり, 脱炭反 応そのものについては詳細な実験をおこなつていない が，脱空反応との関連性を検討するために必要と考えら れる籁囲で検討をおこなつた。

$\mathrm{Ar}+\mathrm{O}_{2}$ 混合ガス $1600 \mathrm{cc} / \mathrm{min}$ で脱炭反応をおこな わせた結坚の一例を Fig. 10 亿示す.これよりあきらか なように溶鋼中の炭素はいずれの場合にも時間とともに 直線的に減少することがわかる. 酸素分圧が $0.1 \mathrm{~atm} の$ 場合の脱炭反応の進行状況は，炭素が約 $0.1 \%$ 付近で fume の発生が認められる. その後酸化膜が湯面中心か らあらわれ，しばらくするとCO のボイリングがおこ る.酸素分氏がさらに高い場合にも, fume は $0 \cdot 1[\% \mathrm{C}]$ 付近で同椂に発生するが，fume が発生してから CO ボ イリングが生ずるまでの時間は酸素分压の増大とともに 短くなり, 酸素分压が $0.3 \mathrm{~atm}$ の場合には, fume の発 生後わずかの時間で CO ボイリングがおこる. 図中に 炭素と窒素を所定量含む溶鋼に $\mathrm{Ar}+\mathrm{O}_{2}$ 混合ガスを吹き 付け, 脱炭反応と脱窒反応を同時におこなわせた場合の 結果もあわせて示す．この場合も時間とともに炭素濃度 は直線的に減少する.しかも脱炭反応のみをおこなわせ た場合とほぼ同じ速度で脱炭反応が進行している．この ことから脱炭反応は脱窒反応と独立して進行しているも のと考えられる.

つきに脱炭速度に方よぼす酸素分圧の影響を Fig. 12 に示す. 脱炭速度は酸素分圧にほぼ比例して上昇してい る.

Fig. 13 に脱炭速度におよぼす温度の影響を示す. 脱

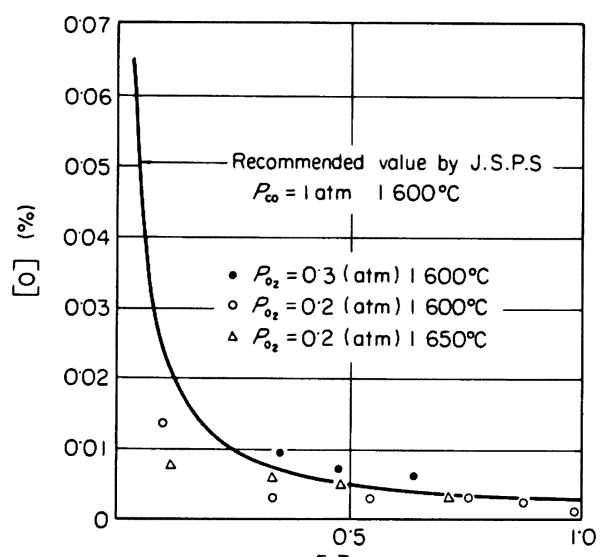

[C] $(\%)$

Fig. 11. Relation between oxygen content and carbon content in liquid iron during decarburizing reaction.
炭反応の温度依存性はきわめて小さいので，その活性化 エネルギーを求めることは困難であるが，Fig. 13 の結 果から脱炭反応の活性化エネルギーを算出すると, 約 $4 \mathrm{kcal} / \mathrm{mol}$ となる. 脱炭反応の活性化エネルギーは従 来多くの研究者らによつて測定されているが21)-29)，一 部を除いて数 $\mathrm{kcal} / \mathrm{mol}$ と報告されている. したがつて 本実験結果は往来の值とそう矛盾していないことがわか る.

\section{5 脱窒反応におよほす脱炭反応の影響}

本実験に拉いて $\mathrm{Ar}-\mathrm{O}_{2}$ 混合ガスをもちいて，酸素分 圧を变化させて, 脱炭反応と同時に脱窒反応をおこなわ せた場合の脱窒速度の検討結柴を Fig. 14 に示す. この ように脱窒速度は 2 次反応の速度式からはずれる. しか も時間の経過ととも沉そのずれは大きくなつている.

Fig. 14 からわかるように， $P_{\mathrm{O}_{2}}$ (したがつて脱炭速度） の影響については，短時間側ではあまり明りょうではな いが $P_{\mathrm{O}_{2}}$ が $0.3 \mathrm{~atm}$ の場合に反応時間の経過とともに

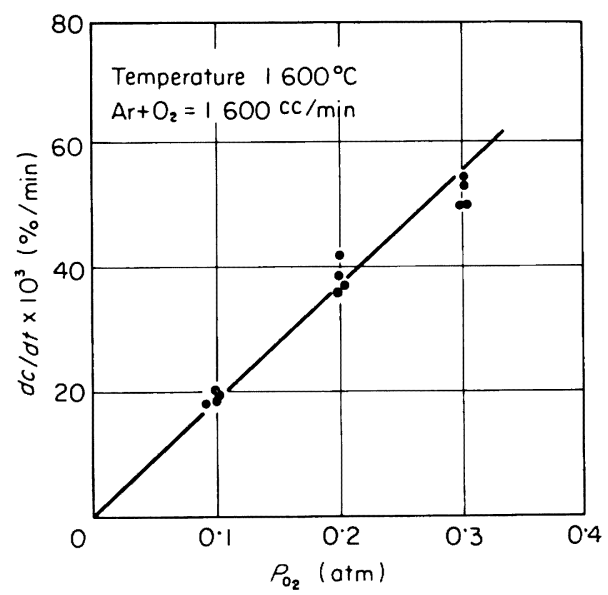

Fig. 12. Relation between reaction rate and partial pressure of oxygen mixed with argon.

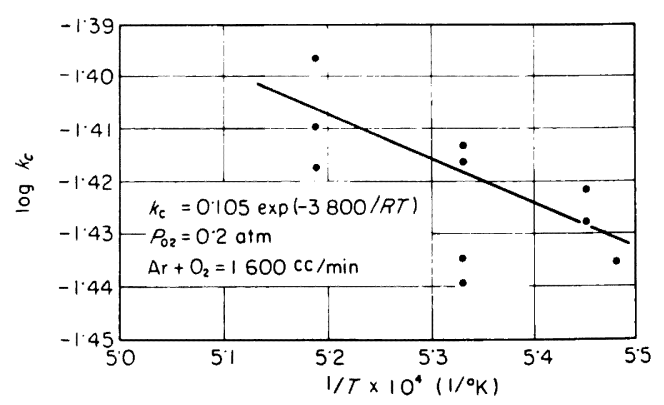

Fig. 13. Effect of temperature on decarburization rate of liquid steel. 


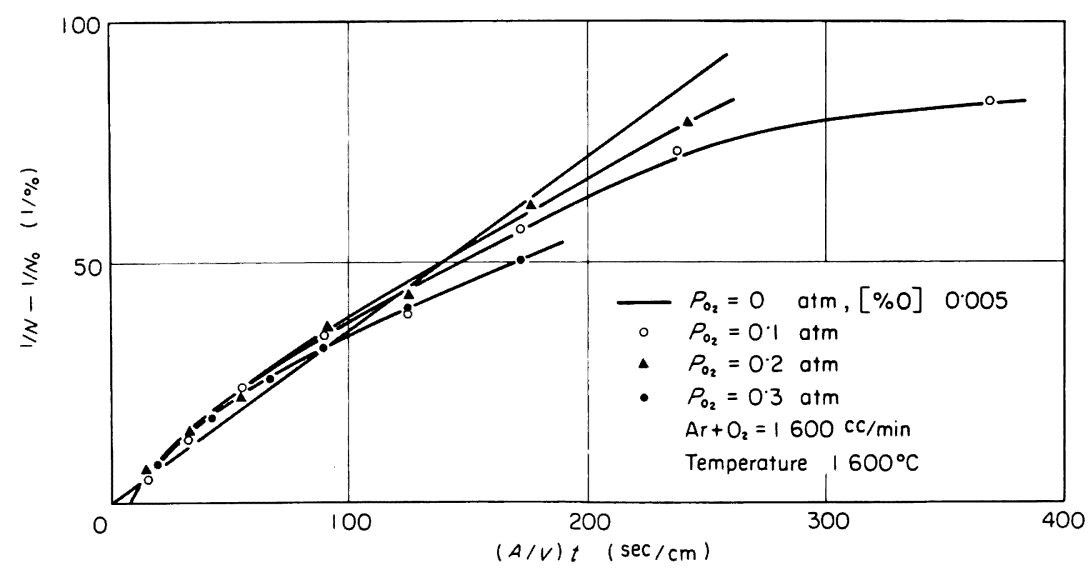

Fig. 14. Relation between $\left(1 / N-1 / N_{0}\right)$ and $(A / V) t$ during the nitrogen desorption of liquid steel by argon and oxygen mixed gas with various oxygen partial pressure.

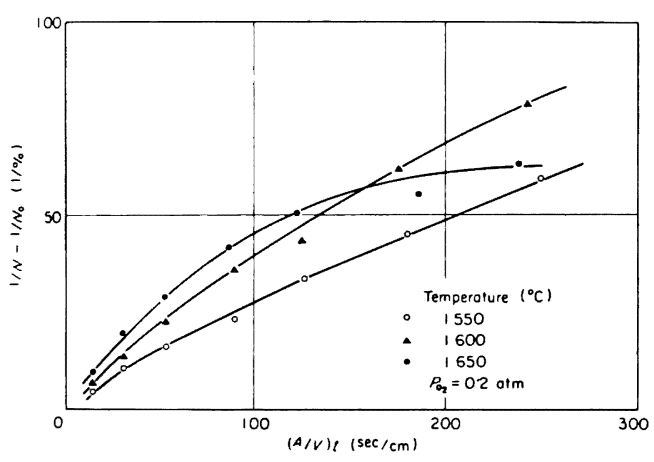

Fig. 15. Relation between $\left(1 / N-1 / N_{0}\right)$ and $(A / V) t$ during nitrogen desorption of liquid steel by argon and oxygen mixed gas at various temperature.

$P_{\mathrm{O}_{2}}$ が 0.1 および $0.2 \mathrm{~atm}$ の場合にくらべて, やや脱 窒速度が抢そくなる傾向がうかがえる.

つぎに $P_{\mathrm{O}}$ ，を $0.2 \mathrm{~atm}$ に一定に保ち，温度を变えた 場合の結果を Fig. 15 示す. この場合も脱窒反応は温 度には無関係にいずれも 2 次反忍の速度式からはずれる が， $1650^{\circ} \mathrm{C}$ の場合のずれは他の場合に比較して大き w.

\section{6 脱窒速度におよぼす炭素の影憬}

脱炭速度と脱窒速度との関係を解析する上で問題とな る脱窒速度におよほすす溶鉄中の炭素の影響について検討 を抢こなつた。この場合も脱窒反応は 2 次反応の速度式 によく一致し, Fig. 16 に示したように, 脱窒反応の速 度定数は $[\mathrm{C}]$ 量の増加とともに大きくなることがわか る.

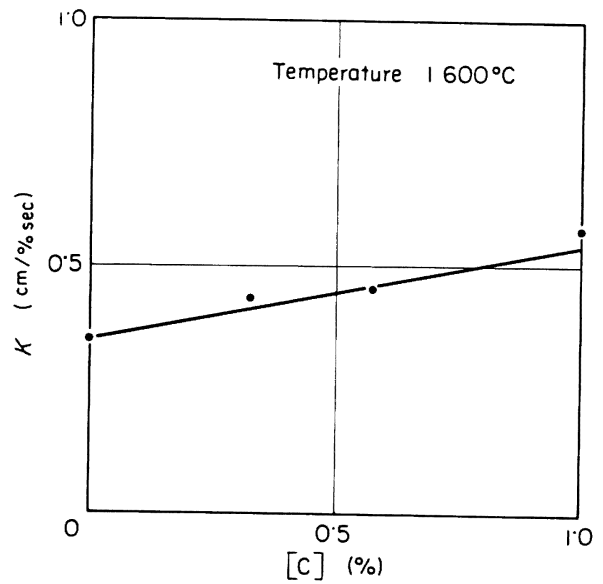

Fig. 16. Effect of carbon content on the rate constant of nitrogen desorption in liquid steel.

\section{4. 考察}

\section{1 溶鉄の脱窒反応機構について}

溶鉄の脱窒反応について, R. D. PEHLKE ら'は $P_{\mathrm{N}}$ $=0.6 〜 1 \mathrm{~atm}$ で実験を沶こない, 脱窒反応は 1 次反応 の速度式にしたがうと報告している。一方，森5)，不破

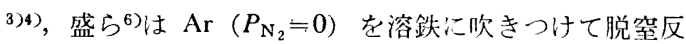
応をおこなわせた結果，いずれも2 次反応の速度式にあ てはまると報告している.

このような実験結果の相違について, 䛶らは $P_{\mathrm{N}}$ ，の 相違によつて溶鉄面上の絰素分子あるいは原子の吸着の 状態がかなり翼なるのではないかと考えて，J.J. ScHO- 
LTEN ら 29 が $300^{\circ} \mathrm{C}$ で间体鉄の空素吸着と脱蜼とについ ておこなつた実駼の解析結果を引用して説明している. つまり窒素に上万表面被覆染が大きく, すなわち $P_{\mathrm{N}_{2}}$ が 大きい場合には mobile adsorption を仮定した計算結果 に实験結果が近いことにより，たとえば $\mathrm{Fe} \mathrm{N}=\mathrm{N}$ のような形で，また被覆率が小さく，すなわち $P_{\mathrm{N}}$ ，が 小さい場合には inmobile adsorption を仮定した計算結 果に近いことにより，たとえば $\mathrm{Fe} \equiv \mathrm{N}$ のような形で吸 着されると考えられている.

そこで楱らは $P_{\mathrm{N}}=0$ の場合には，2つの䆟素原子が

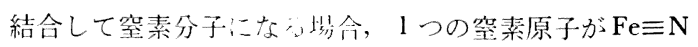
のように強く吸着しておれば，もう1つの穻素原子はか なり弱く吸着したもののほうがェネルギー的に反応しや すいと考え, 脱窒反応はつぎのような各素過程で抗こな われるものと考えている。ただし弱吸着の空素原子と溶 舴劣原子は区別せずNで表わしている。

(1) $\mathrm{N}+L \longrightarrow \mathrm{N}-L$

(2) $\mathrm{N}-L+\mathrm{N} \longrightarrow \mathrm{N}_{2}-L$

(3) $\mathrm{N}_{2}-L \longrightarrow \mathrm{N}_{2}(\mathrm{~g})+L$

ここで $L$ は吸着点, $N-L$ は吸着点と強く結合した塋 素原子を示す。そしてこれらについて速度式を導入し， 彼らの実験結果と比較して脱窒反応の律速段階としては 溶鉄表面における反応過程か，あるいは生成した空素分 子が脱離する過程のいずれかであると結論している.

榙らは以上のように2つの窒素原子が結合して窒素分 子になる場合，1つの攀素原子が強く結合して执杖，

もう1つの窒素原子はかなり弱く吸着したもののほうが エネルギー的に反応しやすいと考えて, 实験結果を解析 している.つまり1座吸着の考え方に近い.

本们析机おいては溶鉄表面に吸着した等素原子が等素 分子を生成する場合, 吸着した窒素原子は同じものであ ると考え， 2 個の吸着突桬原子が反応して $\mathrm{N}_{2}$ になると 敒定し，いわゆる2 痤吸着の考え方を用いて解析在す寸 める.したがつてこの場合の素渦程はつきのように考え られる。

$$
\begin{aligned}
& \text { (4) } \mathrm{N}+L \longrightarrow \mathrm{N}-L \quad \ldots \ldots \ldots \ldots \ldots \\
& \text { (5) } \mathrm{N}-L+\mathrm{N}-L \longrightarrow \mathrm{N}_{2}-L+L \\
& \text { (6) } \mathrm{N}_{2}-L \longrightarrow \mathrm{N}_{2}(\mathrm{~g})+L \cdots \ldots \ldots
\end{aligned}
$$

ここでいずれか 1 つ過程が律速段階であるときに は，その他の過程は平衡状態にあると考元る。濃度は寸 べて表面浱度 $\Gamma$ で表わし, 溶鉄単位表面積および単位 体积について考えれげつきのような3つの啰命の速度式 庭得る。

（i） Nの吸着すなわた（40)文心が律涑の場合， 脱空速度は

$$
-d[\mathrm{~N}] / d t=k_{1}[\mathrm{~N}] \Gamma_{L}-k_{1}{ }^{\prime} \Gamma_{\mathrm{N}-L}
$$

(5)および(6)が平衡であるから，

$$
\begin{aligned}
\Gamma_{\mathrm{N}-L}{ }_{L}= & k_{2}{ }^{\prime} / k_{2} \Gamma_{\mathrm{N}_{-}-L} \Gamma_{L}=K_{2} \Gamma_{\mathrm{N}_{-}-} \Gamma_{L} \\
& \left(K_{2} \equiv k_{2}{ }^{\prime} / k_{2}\right) \\
\Gamma_{\mathrm{N}_{2}-L}= & k_{3}{ }^{\prime} / k_{3} P_{\mathrm{N}_{2}} \Gamma_{L}=K_{3} P_{\mathrm{N}_{-}} \Gamma_{L} \cdots \cdots \\
& \left(K_{3} \equiv k_{3}{ }^{\prime} / k_{3}\right)
\end{aligned}
$$

(11)および(12)式を(10)式に代入すると,

$$
\begin{aligned}
-d[\mathrm{~N}] / d t & =\Gamma_{L}\left(k_{1}[\mathrm{~N}]-k_{1}{ }^{\prime} \sqrt{K_{2} K_{3} P_{\mathrm{N}}}\right) \\
& =\Gamma_{L}\left(k[\mathrm{~N}]-k^{\prime} \sqrt{P_{\mathrm{N}_{2}}}\right) \cdots \cdots \cdots \\
(k & \left.\equiv k_{1}, \quad k^{\prime}=\sqrt{K_{2} K_{3}}\right)
\end{aligned}
$$

ここで $\Gamma_{L}=\Gamma_{l}-\Gamma_{\mathrm{O}-L}-\Gamma_{\mathrm{N}-L}-\Gamma_{\mathrm{N}_{2}-L}$ と才くくこと ができこれに(11)および(12)式を代入し，さらに

$$
\Gamma_{\mathrm{O}-L}=\Gamma_{L} K_{0}[\mathrm{O}]
$$

とすれば,

$$
\Gamma_{L}=\Gamma_{t} /\left\{1+K_{0}[\mathrm{O}]+\sqrt{K_{2}} \overline{K_{3} P_{\mathrm{N}_{2}}}+K_{3} P_{\mathrm{N}}\right\}
$$

$$
\begin{aligned}
& \text { となる、したがつて， } \\
& -d[\mathrm{~N}] / d t=\left[\left\{\Gamma_{t} /\left\{\left(1+K_{0}[\mathrm{O}]+\sqrt{K_{2} K_{3} P_{\mathrm{N}}}\right.\right.\right.\right. \\
& \left.\left.+K_{3} P_{\mathrm{N}_{2}}\right\}\right]\left(k[\mathrm{~N}]-k^{\prime} V \overline{P_{\mathrm{N}_{2}}}\right) \\
& \text { ここで } P_{\mathrm{N}} \fallingdotseq 0 \text { とすれば, } \\
& -d[\mathrm{~N}] d t=\left\{\Gamma_{t} /\left(1+K_{0}[\mathrm{O}]\right)\right\} k[\mathrm{~N}]
\end{aligned}
$$
となる。

(ii) $\mathrm{N}_{2}$ への結合，すなわり(5)の反応が律速する場 合, 脱空速度は,

$$
-d[\mathrm{~N}] / d t=k_{2} \Gamma_{\mathrm{N}-L}^{2}-k_{2}{ }^{\prime} \Gamma_{\mathrm{N}_{2}-L} \Gamma_{L}
$$

(4)拉よび(6)が平衡であることにより，

$$
\begin{aligned}
\Gamma_{\mathrm{N}-L}= & k_{1} / k_{1}{ }^{\prime}[\mathrm{N}] \Gamma_{L}=K_{1}[\mathrm{~N}] \Gamma_{L} \\
& \left(K_{1} \equiv k_{1} / k_{1}{ }^{\prime}\right) \\
\Gamma_{\mathrm{N}-L}= & K_{3} P_{\mathrm{N}} \Gamma_{L}
\end{aligned}
$$

(18)および(12)式を(17)式に代入する.

$$
-d[\mathrm{~N}] / d t=\Gamma_{L^{2}}{ }^{2}\left\{k_{\mathrm{2}} K_{1}^{2}[\mathrm{~N}]^{2}-k_{2}{ }^{\prime} K_{3} P_{\mathrm{N}}\right\} \quad \cdots(19)
$$

ここで $\Gamma_{L}=\Gamma_{t}-\Gamma_{\mathrm{O}-L}-\Gamma_{\mathrm{N}-L}-\Gamma_{\mathrm{N}_{2}-L}$ に(18) およ び(12)式を代入するょ,

$$
\Gamma_{L}=\Gamma_{t} /\left(1+K_{0}[\mathrm{O}]+K_{1}[\mathrm{~N}]+K_{3} P_{\mathrm{N}}\right)
$$

(20) 式を(19) 式に代入すると,

$$
\begin{aligned}
& -d[\mathrm{~N}] / d t=\Gamma_{t^{2}}{ }^{2} /\left(1+K_{0}[\mathrm{O}]\right. \\
& \left.+K_{1}[\mathrm{~N}]+K_{3} P_{\mathrm{N}}\right)^{2}\left\{k_{2} K_{1}{ }^{2}[\mathrm{~N}]^{2--} k_{2}{ }^{2} K_{3} P_{\mathrm{N}}\right\} \\
こ & \text { で } P_{\mathrm{N}} \fallingdotseq 0 \text { とすれば, } \\
- & d[\mathrm{~N}] / d t=\Gamma_{t^{2}} /\left(1+K_{0}[\mathrm{O}]\right. \\
& \left.+K_{1}[\mathrm{~N}]\right)^{2}\left(k_{2} K_{1}{ }^{2}[\mathrm{~N}]^{2}\right) \ldots \ldots \ldots \ldots \ldots \ldots \ldots \ldots \ldots \ldots
\end{aligned}
$$

さらに $1+K_{0}[\mathrm{O}] \gg K_{1}[\mathrm{~N}]$ とすれば,$$
\left.-d[\mathrm{~N}] / d t=\left\{\Gamma_{t} /\left(1+K_{0} ! \mathrm{O}\right]\right)\right\}^{2}\left(k_{2} K_{1}^{2}[\mathrm{~N}]^{2}\right)
$$

となる。

(iii) $\mathrm{N}_{2}$ の脱離，すなわら(6)の反応が律速の場合， 脱空速度は, 
$-d[\mathrm{~N}] / d t=k_{3} \Gamma_{\mathrm{N}_{2}-L}-k_{\mathrm{s}}{ }^{\prime} P_{\mathrm{N}_{2}} \Gamma_{L}$

(4)抢よび(5)が平衡にあることにより，

$$
\begin{aligned}
& \Gamma_{\mathrm{N}-L}=K_{1}[\mathrm{~N}] \Gamma_{L} \\
& \Gamma_{\mathrm{N}-L}^{2}=K_{2} \Gamma_{\mathrm{N}_{-}-L} \Gamma_{L}
\end{aligned}
$$

(18)および(11)式を(24)式に代入すると，

$$
\begin{gathered}
\begin{aligned}
-d[\mathrm{~N}] / d t & =\Gamma_{L}\left(k_{3} K_{1}^{2} / K_{2}[\mathrm{~N}]^{2}-k_{3}{ }^{\prime} P_{\mathrm{N}_{2}}\right) \\
& =\Gamma_{L}\left(k[\mathrm{~N}]^{2}-k^{\prime} P_{\mathrm{N}}\right) \cdots \cdots \cdots \cdots \cdots \cdots(25) \\
& \left(k \equiv k_{3} K_{1}{ }^{2} / K_{2}, \quad k^{\prime} \equiv k_{3}{ }^{\prime}\right)
\end{aligned} \\
\text { ここで } \Gamma_{L}=\Gamma_{t}-\Gamma_{\mathrm{O}-L}-\Gamma_{\mathrm{N}-L}-\Gamma_{\mathrm{N}-L} \text { (11),(18) }
\end{gathered}
$$

式を代入すると，

$$
\Gamma_{L}=\Gamma_{t} /\left(1+K_{0}[\mathrm{O}]+K_{1}[\mathrm{~N}]+K_{1}{ }^{2} / K_{2}[\mathrm{~N}]^{2}\right) \cdots
$$

(26)式を(25) 式に代入すると，

$$
\begin{aligned}
& -d[\mathrm{~N}] / d t=\Gamma_{t} /\left(1+K_{0}[\mathrm{O}]+K_{1}[\mathrm{~N}]\right. \\
& \left.+K_{1}^{2} / K_{2}[\mathrm{~N}]^{2}\right)\left(k[\mathrm{~N}]^{2}-k^{\prime} P_{\mathrm{N}}\right) \\
& \text { ここで } P_{\mathrm{N}} \fallingdotseq 0 \text { とすると， } \\
& -d[\mathrm{~N}] / d t=\left\{\Gamma_{l} /\left(\mathrm{l}+K_{0}[\mathrm{O}] \cdots K_{1}[\mathrm{~N}]\right.\right. \\
& \left.\left.+K_{1}^{2} / K_{2}[\mathrm{~N}]^{2}\right)\right\} k[\mathrm{~N}]^{2} \\
& 1+K_{0}[\mathrm{O}] \gg K_{1}[\mathrm{~N}]+K_{1}^{2} / K_{2}[\mathrm{~N}] 2 \text { とすると, } \\
& -d[\mathrm{~N}] / d t=\left\{\Gamma_{t} /\left(1+K_{0}[\mathrm{O}]\right)\right\} k[\mathrm{~N}]^{2}
\end{aligned}
$$

レなる。

以上のように2 座吸着を考虑して，(4)，(5)よび(6)の 各素過程が律速段階と考えられる場合の反応式を導入し たＡＡを吹きつけて脱窒反応をおこなわせた場合，乙

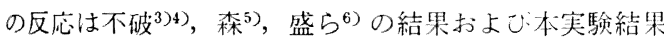
はこもに2 次反応の速度式にしたがう２２座吸着の考元 こしたがつて得られた吸着律速式 (16) 式は 1 次式であ る.したがつて吸着律速ということは考えられない、一 方 $\mathrm{N}_{2}$ の結合， $\mathrm{N}_{2}$ の脱離が律畒卞る場合には (23) 求よ ヨ゙(29)式で示されるように脱空反応は 2 状反応の速度式 にしたがう、したがつて $\mathrm{N}_{2}$ の結合， $\mathrm{N}_{2}$ の艄唯のいず れかが律速段階になると考えられる.

森らの結果に上れば，速度定数は約 $0.01[\% \mathrm{O}]$ 以上 でほぼ酸素濃度に逆比例し, 不破らの結桇に上れば, 速 度定数は $0.03 \sim 0.1[\% \mathrm{O}]$ で酸素濃度の 1.5 耕に逆比 例する. 本実験結独では $0.03 \sim 0.075[\% \mathrm{O}]$ で不破ら の結果よりさらに酸素の影響は大きく，速度定数は酸素 䟴度のほぼ 2 乘に逆比例する。

2 座吸着を仮定して $\mathrm{N}_{2}$ の結合が律贱すると考えた場 合，(23)式において酸素濃度が高い場合には $K_{0}[\mathrm{O}] \gg 1$ と考えられるので, 速度定数は酸素浱度の 2 乘に逆比例 する. 一方, $\mathrm{N}_{2}$ の脱離が律速する場合, (29) 式において 同样に考えると速度定数は酸素濃度に逆比例する.

したがつて本実駼結㷊から考えると，高酸素濃度では 吸着した空素原子 2 個が結合して $\mathrm{N}_{2}$ になる反応が脱窒 反応の律速段階になると推論される.

\section{$4 \cdot 2$ 脱炭反応に関する考察}

脱炭反応の速度諭的研究は実駼至的規枌における比較 的に O 供給量の少ない場合から, 実際の転炉，電弧炉， 平炉に悲ける $\mathrm{O}_{2}$ 供給量の多い場合にいたるまで多くの 研究がある. 木破兊は脱案反応の機構の解明が目的であ り，したがつて脱炭反応そのものについては詳細な実験 を抢こなつていないが，脱空反応との関速性を検討する ために実験結果について簡単に考多老おこなう。ただし 本㱛究では溶鉄中の炭素が $0.2 \sim 0.3 \%$ 以上の比較的高 炭素頒域での脱炭反応にかきつて考察をす寸方る。

ガス境膜内の $\mathrm{O}:$ の拡散が律速正る場合には，静止境 界層中での定浮拡散式から, 脱炭速度は $\log \left(1+P_{\mathrm{O}}\right)$ 江 比例し，一方溶銅表面に吸瘖した $\mathrm{O}_{2}$ が活性な $\mathrm{O}_{2}$ をへ て解離する段階が律速段階よなる反応律速の場合には, 脱炭速度は $P_{\mathrm{O}}$ ，に比例する。

Fig. 17 に脱炭速度と $\log \left(1+P_{\mathrm{O}_{2}}\right)$ の関係寺示吉. Fig. 12 に示した脱炭速度上 $P_{O}$ ，の関倸执よび Fig. 17 の結果の比較からは，本実䮖条件での脱炭反応の律速段 階をいずれとも明確に判断することはできない。

森山 3031 ) (脱炭反応について化学反応とガス境膜内

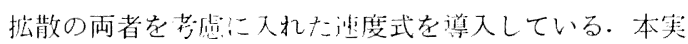
験結尖に森山らの解析方法を適用し, 総括反応抵抗に対 する化学反応抵抗の比率を計算吉っと0.7 と亦り, 本実

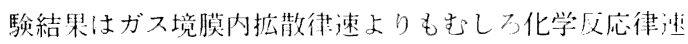
に近いという結果になる.

つぎに活性化エネルギーに関しては，通浣，ガスの拡 散の活性化エネルギーは数 $\mathrm{kcal} / \mathrm{mol}$ 程度であることを 考える上, 本実験結相の活性化エネルギ一約 $4 \mathrm{kcal} / \mathrm{mo}$ ! は添それに近い。

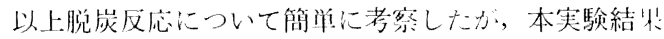
からだけでは脱炭反応の律速段階について明確な結論を 下すことはできない。すなわち化产度应律速あるいはガ

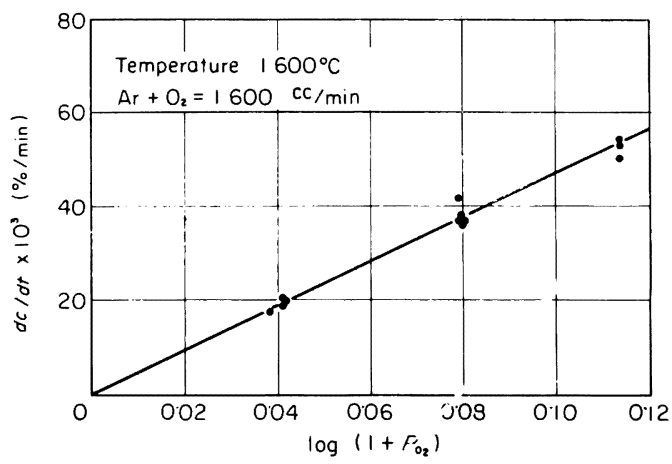

Fig. 17. Relation between decarburization rate and oxygen partial pressure. 
ス境膜内拡散律速のいずれとも断定できず，むしろ混合 律速である可能性がある.

\section{3 溶鋼の脱窒反応に関する考察}

脱窒反応におよぼす合金元素の影響については，不破 ら4)が多くの合金元素について研究を抢こなつている. 不破らの結果によると [C]， [Si] のような元素はとも に比較的低濃度範围で見かけの脱窒速度定数を大きくす るが，ある濃度以上ではほぼ一定の值になる。これまで の研究によれば, [C]，[Si] ともに表面張力におよぼす 影響は小さく，表面活性元素とは考えられない32333)した がつてこれらの元素は脱酸元素として作用し，溶鉄中の 酸素量を下げることによつて脱空速度に間接的に影響を およぼすものと推測している.

さらに不破らは溶鉄の脱窒速度は界面に吸着された窒 素が化学反心により空素分子を生成し, 生成物が脱着す る過程が律速段階であると仮定し，実験で得られた速度 定数と [O] との関係式をつぎのように求めている.

$$
\begin{aligned}
& \left.K_{2}{ }^{\prime}=0.9743 f_{\mathrm{N}^{2}}{ }^{\prime}, \frac{1}{1+28 \cdot 40[\% \mathrm{O}]}\right)^{2} \\
& \text { そして (30)式で Fe-O-X 系の場合には， } \\
& \log K_{2}{ }^{\prime}+2 \log (1+28 \cdot 4[\% \mathrm{O}])-2 \log f_{\mathrm{N}}^{\mathrm{O}} \\
& =\log 0 \cdot 9743+2 e \underset{\mathrm{N}}{\mathrm{X}}[\% \mathrm{X}]
\end{aligned}
$$

の関係が成立し, $[\mathrm{C}]$ 上 $\mathrm{Si}]$ の高浱度範囲を除けばこ の式が満足される.しかし高浱度範囲では $K_{2}{ }^{\prime}$ は一定の 值になる。これ上り不破らは脱窒反応はこれらの共存元 素の高濃度の範囲では律速段階が反応界面への $[\mathrm{N}]$ の移 動律速に変わると推測している.

(1)式に示した脱窒速度式は正確には活量をもちいて

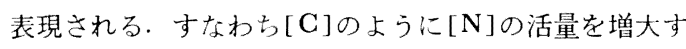
る元素が共存する場合の脱空速度は純鉄の場合のそれに くらべてほぼ $\left(f_{\mathrm{N}}^{(\mathrm{C})}\right)^{2}$ 倍はやくなる。すなわち $\mathrm{Fe}-\mathrm{C}$ 采の 速度定数と純鉄の速度定数の比は $\left(f_{\mathrm{N}}^{(\mathrm{C})}\right)^{2}$ になるはずで ある・そこで本実験絬思についてその值を計算した結果 をFig. 18 に示す. 図中の 2 本の曲線は H. S $\mathrm{SHEN} \mathrm{CK}^{35}$ ${ }^{36)}$, 前川ら ${ }^{37)}$ の相互作用助係数を用いて計算した $\left(f_{\mathrm{N}}^{(\mathrm{C})}\right)^{2}$ の值である.この図からわかるように，本実験結果の $\left(f_{\mathrm{N}}^{(\mathrm{C})}\right)^{2}$ の值は平衡実験から求められた $\left(f_{\mathrm{N}}^{(\mathrm{C})}\right)^{2}$ の值よ り多少低いが傾向としては比較的よく一致している.

良来の吸窒反応の研究において ${ }^{38339)}$ ，さらに前述の不 破らの報告にもあるように，溶鋼中に酸素の活量を低下 させる元素が存在する場合には, 低搌度の添加でその速 度をはやめることが知られている．本実験では [C] が $0.4 \sim 1.0 \%$ の範囲しか実験していないが，この範囲で は脱空速度の増大はほぼ溶鋼中の $[\mathrm{C}] か ゙[\mathrm{~N}]$ の活量を増 加させることに起因しているものと推察される.

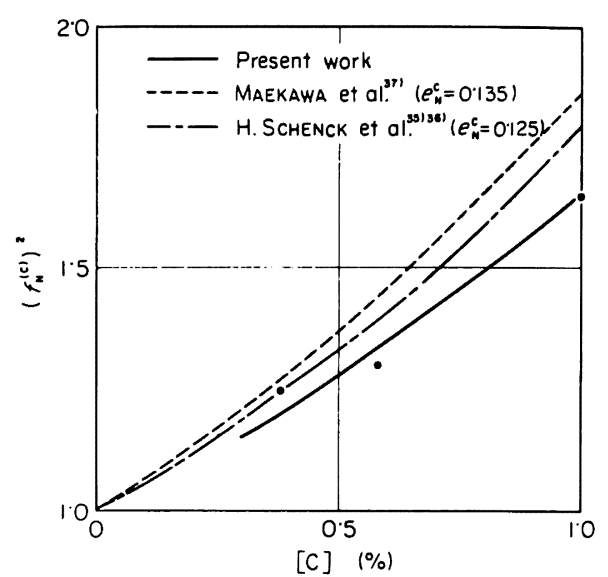

Fig. 18. Relation between the activity coefficient, $f_{\mathrm{N}}^{\mathrm{C}}$ ' and carbon content.

つぎに脱空速度におよぼす脱炭反応の影響について考 察する.

脱炭反応上脱窒反応を同時におこなわせた場合には, 溶鋼中の炭素濃度が減少するのにともなつて活量係数 $f_{\mathrm{N}}^{(\mathrm{C})}$ も連続的に減少していくので，[N] の活量に対す る $[\mathrm{C}]$ の影響のみを考虑しても脱空速度は反応時間の経 過とともに減少することになり，2 次反応の速度式から 当然はずれることになる。しかも $f_{\mathrm{N}}^{(\mathrm{C})}$ は連続的に变化 するので脱窒速度式を解析的に皘分することは不可能て ある・

そこで脱炭反応と同時に脱空反応をおこなわせた場合 の脱窒速度の变化を $[\mathrm{C}]$ の減少にともなう $[\mathrm{N}]$ の活量の 変化のみに基因するものかどうかを調べるために，つぎ のような解析をおこなつた。すなわち溶鋼中の[C]の時 間的推移として実測結果をもちいて各反応時間での $f_{\mathrm{N}}^{\mathrm{C}}$ を計算し, その值を脱窒速度式に代入し, さらに脱窒速 度定数として純溶鉄（[O] $=0.005 \%)$ での実測值をもち いて, Runge Kutta法による数优積分によつて $[\mathrm{N}]$ の経 時変化を計算した，その結果を実測結果と比較してFig. 19 に示す.ささらにこの結果から $\left(1 /[\mathrm{N}]-1 /[\mathrm{N}]_{0}\right)$ と $(A / V) t$ との関係を求めた結果を Fig. 20 に示す.

Fig. 19 あるいは Fig. 20 に示した数值計算結果に おいて， $P_{\mathrm{O}}$ ，が小さく，したがつて脱炭速度が沶そい方 が脱空速度がはやくなつているのは, 同じ反応時間にお ける炭素濃度は脱炭速度のおそいものほど当然高く, し たがつてそのときの $f_{\mathrm{N}}^{(\mathrm{C})}$ が大きいことに基因するもの である. 実測結果の脱窒速度はこのように $f_{N}^{(C)}$ の变化 のみを考虑して計算した結果にくらべてかなり小さくな つている.しかもその相違は反応時間の経過とともに大 きくなる傾何が認められる．Fig. 20 に示した各実測曲 
線の勾配は $k\left(f_{\mathrm{N}}^{(\mathrm{C})}\right)^{2}$ の值を示していると考えられる.

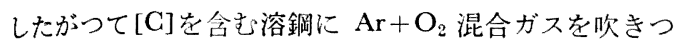
けて脱炭反応と同時に脱窒反応をおこなわせた場合の脱

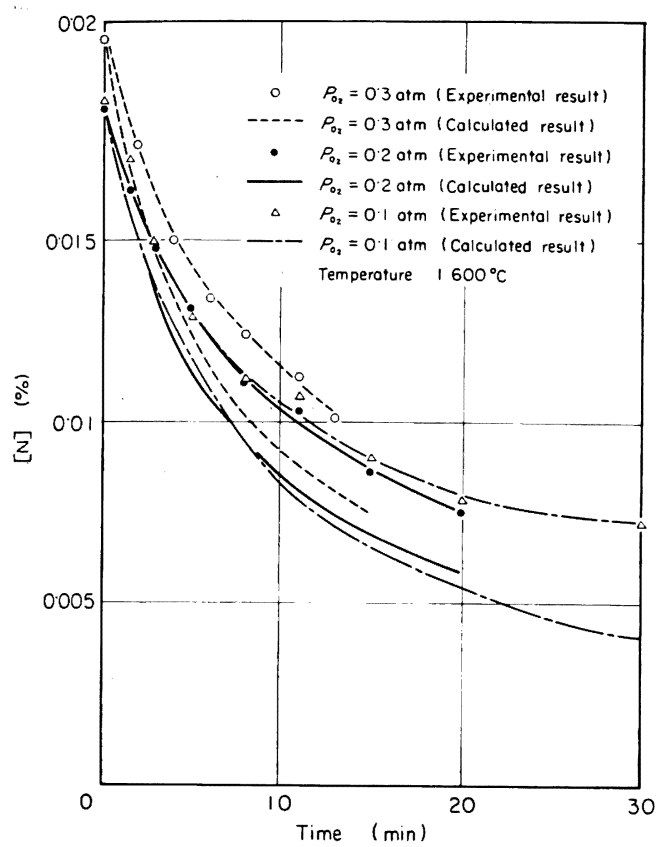

Fig. 19. Comparison of the experimental and the calculated results of the nitrogen desorption rate of liquid steel by argon and oxygen mixed gas.
窒速度の低下は速度定数 $k$ 自体の变化に起因すると考元 られる。しかも現象的には速度定数の減少は，[C]が共 存することにより $[\mathrm{N}]$ の活量が增加すること（すなわち $f_{\mathrm{N}}^{(\mathrm{C})}>1$ になること）にもしずく脱窒速度の増加を上ま わるものであり，女大脱炭方進行して炭素量が減少する のにともなつてその減少割合が大きくなる。本実験範网 では, この速度定数 $k$ 自体の変化に対する $P_{\mathrm{O}_{2}}$ の影響 を明確に冰めることはできなかつた。この問題に関して はさらに検討が必要である.

前述したょう江，溶鉄中の酸素濃度が増加すると速度 定数は減少与ることが忍わられている。これは酸素濃度 の増加にともなつて溶鉄表面での吸着酸素が増加し，そ

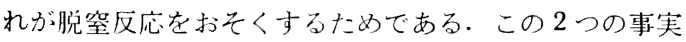
をあわせて考えると，溶鋼に酸化性ガスを吹きつけた場 合に溶鋼表面に吸着した酸素は急凍に $[\mathrm{C}]$ と反応すると してもやはり脱窒反応に影䪪をおよぼすことが示唆され る. さらに脱炭反応が進み炭素量が減少するにともなつ て，この吸着酸菜の作用がより顥著にあらわれることは 容易に推察しうる.

転炉においては大まう口区别して3つの精鉙時期に対 応して脱窒挙動が異㐫るこ上が郝告されているが16)，そ の場合に脱炭がもつ上るさかんに進行寸る時期では脱窒 反応が停滞するここが指摘されている．通常この時期の 脱炭反応は主として $\mathrm{O}_{2}$ ガスと直接接触する溶鋼表面近 傍で進行し，錩浴内部では脱炭にともなう CO 気泡の 発生が少ないことが㤎めた狄ている。すなわ台本研究に おいて指摘したように，实际の転炉吹鍊に扔いても溶鋼

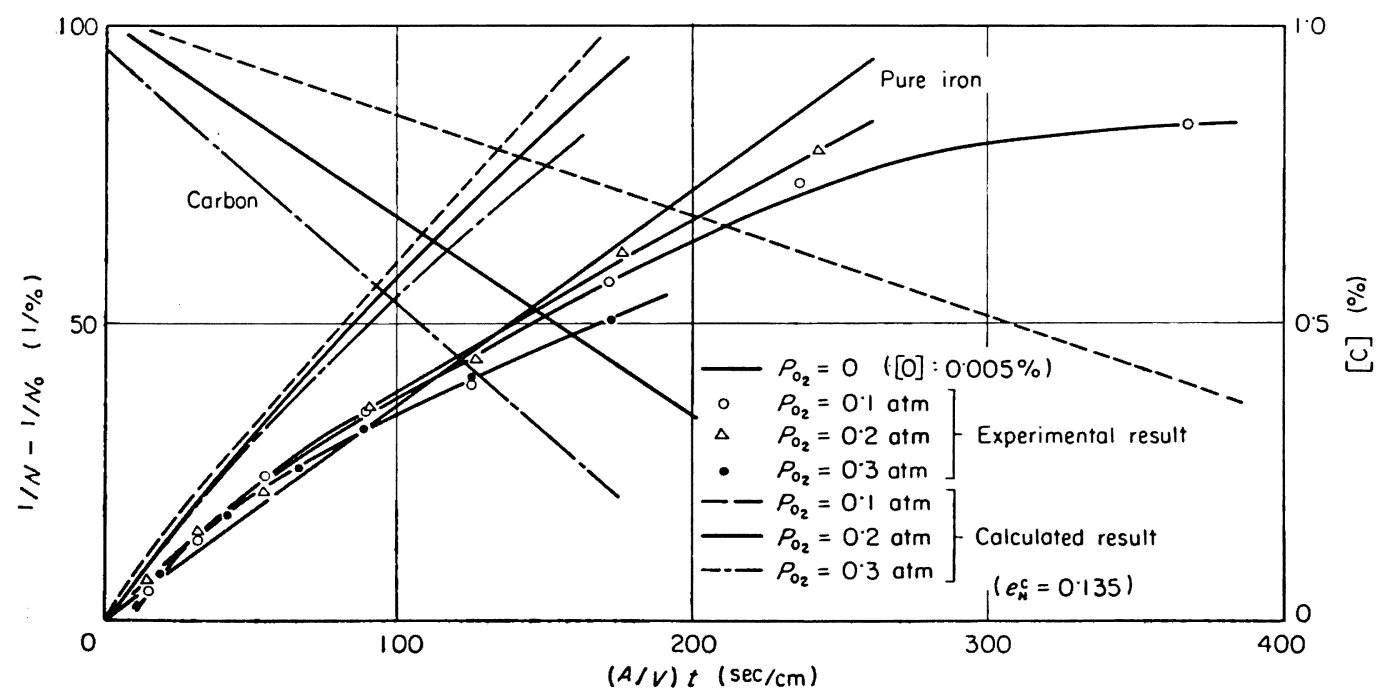

Fig. 20. Comparison of the experimental and the calculated results of the relation between $\left(1 / N-1 / N_{0}\right)$ and $(A / V) t$ during nitrogen desorption of liquid steel. 
衣面での吸着酸素の作用が脱空反応を阻止する1つの原 因となつていることが考えられる。したがつて眃炉吹鍊 において脱炭反応にともなつて脱空反応を促進するため には， $\mathrm{O}_{2}$ ガスと直接接蚛しない鋼浴内部あるいは鋼浴一 炉壁界面からの $\mathrm{CO}$ 匃泡発尘を促進するような吹錐条作 をとることが必要である。

\section{5. 結言}

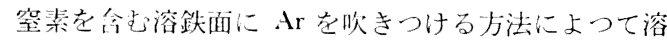

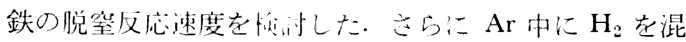
合した場合の脱等隹度の変化，および $\mathrm{Ar}+\mathrm{O}_{2}$ 混合ガス によつて溶鋼の脱窒反芯上同㭙汇脱炭反応をおこなわせ た場合の脱空速度の変化こついて惟討をおこない，つき のような結果を得た

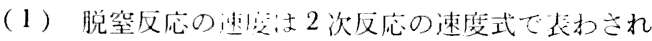
る・したがつてその反芯の徘速段階は界面反応であると 考えられる.

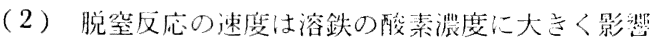

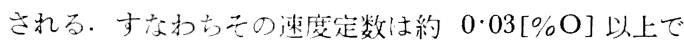

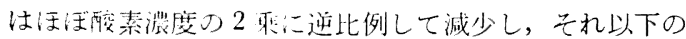
酸素渺度ではその变化はしだいに小さくなり，0.01[\% O]以下では活涪一定值と夜る。

(3) 酸素浱度が $0.01 \%$ 以下の溶鉄での脱空反応の 活性化エネルギーは約 $39 \mathrm{kcal} / \mathrm{mol}$ である.

（4）高酸素浱度 $(0.03[0 \% \mathrm{O}]$ 以上）の溶鋼での脱 窒反応の律;速段階は溶鉄表面に吸着した窒素原子 2 個が $\mathrm{N}_{2}$ 沉なる過程であると推緰した。

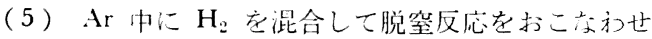
ると脱空速度は速くなる。これは溶鉄表面に吸着した酸

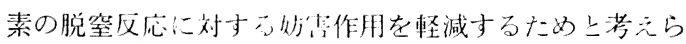
れる.

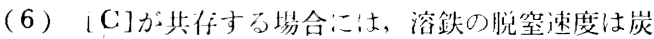
溸浱度の增加ととも沉はやくなる。これは炭素が空素の 活量を上湆ることに主上して基因与る。

（7） [C]<1\% の領域に打ける脱炭反态の活性化工 ネルギーとして約 $4 \mathrm{kcal} / \mathrm{mol}$ が得られた。

(8) $\mathrm{Ar} \div \mathrm{O}_{2}$ 混合ガスで脱炭々灾と脱窒反応を同時 におこなわせた場会沪は，Ar により脱咥反惢のみをお こなわせた場合にくらべて脱空速度は低下寸る。この脱 窒速度の佂下は溶鋼江凌化性ガスを吹きつけた場合に溶 鋼表面に吸滔した酸素活急速に $[\mathrm{C}]$ こ反応するとしても やはり脱豊反応に影響をおよぼすためと考えられる。

\section{文献}

1) R. D. Pehlek and $J$. F. Elliott: Trans. AIME, 277(1963), p. 844
2) 瀬川，中村，桑原：鉄と鋼，54(1968)，10, S 436

3 ）不破，萬谷，㤵原：鉄と鋼，53(1967)，10, S 328

4 ) 不破, 萬谷, 箣原, 戸崎: 学振 19 委 8937 (昭和 44 年 5 月)

5 ) 鈴木, 森, 伊藤：鉄と鋼，55(1969)， p. 877

6 ) 盛, 姉崎: 学振 19 委, 8782 (昭和 43 年 7 月)

7 ) 新名，高見：鉄と鋼，55(1969)，11，S 473

8 ) $K$. G. Speith and $H$. Bücken: Stahl u. Eisen, $74(1954)$, p. 1648

9 ) D. L. McBride: J. Metals, 12(1960), p. 531

10) $H$. Voigt and G. Mahn: Stahl u. Eisen, 84 (1964), p. 1120

11) $P$. Baumgarten, $T$. Kootz, and $E$. E. HofMAN: Stahl u. Eisen, 85(1965), p. 1165

12) $H$. vom Ende and $W . D$. Liestmann: Stahl u. Eisen, 86(1966), p. 1189

13) $H$. Íegami, $H$. Ishikawa, and $A$. Horigome: JISI, 206(1968), p. 345

14）川崎製鉄，千葉：话31回製鋼部会資料，(1965.7)

15）住友金属，和歌山：第31回製鋼部会資料, (1965.7)

16）富士製鉄，室萰：籁43回製鋼部会資料，(1969·7）

17) $G$. Mahn, $P$. Ottmar, and $H$. Voigt: Stahl u. Eisen, 89(1969), p. 262

18）日本鋼管，技研：㭊43回製鋼部会資料，(1969.7）

19) $H$. $P$. HaAstert, $E$. Köhler, $F$. Regneri, and E. Schürmann: Stahl u. Eisen, 89(1969), p. 24

20) 森，提，川合：鉄と鋼，52(1966)，p. 507

21）坂上：鉄と铜，52(1966), p. 1738

22) N. N. Drozdov and S. I. Filippov: Cherna. Met, 5 (1967), p. 11

23) 藤井, 荒不: Tetsu-to-Hagané Oversea, 5(1965), p. 290

24) 丹羽, 渡辺, 伊藤, 前川, 中川: 学振19委, 4791

25）郡司，片瀬，青木：鉄と鋼，50 (1964), p. 1828

26) 片瀬，郡司，青木：鉄と鋼，53(1967)，p. 764

27）伊藤，佐野：鉄と鋼，50(1964), p. 873

28) 前川, 中川, 岸田: 鉄と鋼, 46 (1960), p. 1233

29) $J . J$. Sholten, $P$. Zwiertering, $J$. A. KonvaLiNkA, and $J$. $H$. DeBoer: Trans. Faraday Soc., 55(1959), p. 2166

30) 森山，鞭：金属学会誌，29(1965), p.741

$31)$ 森山, 鞭：金属学会誌, 29(1965), p. 1165

32) $P$. Kozakevich and $G$. Urbain: Mem، Sci. Rev. Met., 58(1961), p. 931

33) 門間，須藤：日本金属学会誌，24(1960), p. 163

34) 不破, 萬谷: 学振19委 9036 (昭和45年 1月)

35) $H$. Schenck, $M$. Frohberg, and $H$. Graf: Arch. Eisenhüttenw., 29(1958), p. 673

36) $H$. Schenck, $M$. Frohberg, and $H$. Graf: Arch. Eisenhüttenw., 30 (1959), p. 533

37) 前川, 中川: 鉄と鋼, 45(1959), p. 255

38）長, 井上：鉄と鋼，53(1967)，p. 1393

39）圭，岡村，井上：鉄と鋼，55(1969), 1176 